\title{
Preparation and Evaluation of Antioxidant, Antimicrobial Activity of Seaweed (Kappaphycus alvarezii) based Herbal Hair Oil Formulation
}

\author{
Pradeepa Duraisamy ${ }^{1 *}$, Keerthika $S^{2}$, Aswani Ram Vinod ${ }^{3}$ and Dhana Rangesh Kumar $V^{4}$ \\ $1 \& 4$ - Assistant professor, 2 \& 3 - Postgraduate student \\ PG and Research Department of Biochemistry, \\ Dr. N.G.P Arts and Science College (Autonomous), Coimbatore - 641048.
}

*Author for correspondence (Email: pradeepaduraisamy@gmail.com)

\begin{abstract}
The present uses of seaweed Kappaphycus alvarezii are as human foods, cosmetics, fertilizers,

and for the extraction of industrial gums, chemicals and most importantly seaweeds are rich in source of Omega-3 fatty acid. The aim of present study involves preparation of poly herbal hair oil using methanol extract of brown seaweed and the other herbal plants. The prepared herbal oil was subjected to phytochemical screening, antioxidant activity, antibacterial activity, general characterization, physical and biological evaluation. The current study involves preparation of poly herbal hair oil using Kappaphycus alvarezii, Aloe barbadensis miller, Murrays Koenigii and Ocimum tenuiflorum. The oil was prepared according to Ayurvedic pharmacopeia. The prepared formulations are assessed for primary skin irritation test on our forearm. The above said parameters were found to be good and within the standards. All the values in the evaluation of finished K. alvarezii based herbal oil showed that they are within the acceptable limits. It is a very good attempt to establish the herbal hair oil containing methanol extracts of red seaweed and the other herbal plants. Hence, it is concluded that the oil is beneficial in maintaining good growth of hairs, turning grey hairs to black, providing protection from dandruff, and results in lustrous looking hairs.
\end{abstract}

Keywords: Kappaphycus alvarezii, Antioxidant activity, Antibacterial activity, Poly herbal hair oil. 


\section{Introduction}

Hair is a protein filament that grows from follicles found in the dermis. Hair is one of the most important of our body that improves the overall appearance of a person [1]. The hair fall, dandruffs, split ends, grey hair are the major problem associated with hair. To overcome these problems, we use lots of cosmetics [2]. Among these, hair loss (alopecia) is a universal problem having affected both sexes of all races to different extents for as long as mankind has existed [3]. The hair care industry has become aware of this and delivering active products directed towards meeting this consumer demand. In traditional Indian system of medicine many plants and herbal formulations are reported for hair growth promotion as well as improvement of quality of hair [4]. Hair oils are the hair care formulations applied for treatment of hair disorders such as baldness, aggression of hair, discolouring of hair, hair falling, dryness of hair. Herbal hair oils are formulations with herbal extracts in an oil base $[5]$.

Seaweeds are marine algae that are rich source of proteins, $\omega 3$ and $\omega 6$ polyunsaturated fatty acids, vitamins, minerals and fiber [6]. In Japan, China and Korea seaweeds are traditionally consumed as food or used as fertilizer and animal feed additives. Based on pigmentation they are broadly grouped into three different classes: green (Chlorophyceae), brown (Phaeophyceae) and red (Rhodophyceae) algae. Kappaphycus alvarezii, is an edible red seaweed found in Malaysia, Kenya, China and India. They are also cultivated in coastal areas as it is one of the most important commercial sources of carrageenan, a family of gel-forming polysaccharide. Kappaphycus spp. have high carrageenan content and diverse industrial applications [7]. In food industry they are used as gelling and emulsifying agent. In dairy products, carrageenans are used at low concentration to prevent fractionation of milk constituents. They are also used in pharmaceutical formulations and cosmetics.

Seaweed extracts are a rich source of structurally diverse bioactive compounds, and it has a great potential to be used as a natural biomaterial. There are some reports that have shown anti-viral [8], anti-tumour [9], anti-inflammatory, anti-microbial [10] and antioxidant [11] activities of different seaweeds.

The concept of beauty and cosmetics is as ancient as mankind and civilization. So, they use various beauty products that have herbs to look charming and young. Indian herbs and its significance are popular worldwide [12]. Herbal cosmetics have growing demand in 
the world market and are an invaluable gift of nature. There are a wide range of herbal cosmetic products to satisfy beauty regime. Adding herbs in cosmetics is very safe for our skin [13-15]. Herbal hair oils are one of the most well recognized hair treatments. Herbal hair oil not only moisturizes scalp but also reverses dry scalp and dry hair condition. It provides numerous essential nutrients required to maintain normal functions of sebaceous gland and promote natural hair growth [16].

The intake of seaweed $K$. alvarezii helps to promote scalp hydration, which improve the condition of dry hair. Seaweed can also increase hair mineralisation, which leads to thicker hair. A very few studies focused on the hair growth activity of the seaweed. Hence, the main aim of the present study is, formulation and evaluation of seaweed Kappaphycus alvarezii based herbal hair oil.

\section{Materials and methods}

\section{Collection of plant materials}

The fresh red seaweed (Kappaphycus alvarezii) collected from the rocks of Indian Ocean, Kanyakumari district, Tamil Nadu. Then the seaweeds were washed thoroughly with seawater to remove extraneous materials and brought to the laboratory in plastic bags containing water to prevent evaporation. Samples were then shade dried in till constant weight obtained and ground in pulverization to get coarse powder. The powdered samples subsequently stored. And other herbal plant materials Aloe barbadensis miller, Murrays Koenigii and Ocimum tenuiflorum were collected from our college herbal garden.

\section{Preparation of seaweed extract}

The dried seaweed was coarsely powdered and $250 \mathrm{~g}$ of this seaweed powder was packed in Soxhlet extractor of $500 \mathrm{ml}$ capacity. The solvent methanol was added into the flask and heated. The temperature was maintained at $60^{\circ} \mathrm{C}$ to $70^{\circ} \mathrm{C}$ throughout the extraction. The soluble active constituents of the extract remained in the flask and the process was repeated until the compounds were completely extracted. The liquid extract was then cooled and concentrated by using a rotary evaporator at $30-45^{\circ} \mathrm{C}$. The extract was stored in labelled sterile screwcaped bottle at $4^{0} \mathrm{C}$ until it was used.

\section{Phytochemical screening of methanol extract from Kappaphycus alvarezii}

The qualitative phytochemical screening of $K$. alvarezii (methanol extract) is assayed by standard methods [17]. The screening was carried out to discover the significant bioactive components such as tannins, saponins, flavonoids, phenols, terpenoids, alkaloids, glycosides, cardiac glycosides, coumarins, and steroids.

\section{Antioxidant activity}


Different concentrations $(50-250 \mu \mathrm{g} / \mathrm{ml})$ of $K$. alvarezii (methanol extract) were tested for various types of radicals scavenging potential. Ascorbic acid was used as standard reference compound for all in vitro antioxidant assays.

\section{Free Radical Scavenging Activity on DPPH.}

The antioxidant activity of the sample was determined in terms of hydrogen donating or radical scavenging ability, using the stable radical DPPH, according to the method of Blois (1958) [18].

\section{Superoxide Radical Scavenging Activity}

Superoxide radicals were generated by a modified method of Beauchamp and Fridovich (1971) [19].

\section{Fourier Transform Infrared (FTIR) Analysis}

FTIR (Model Avatar, 370 Spectrometer, Thermo Nicolet Corporation, Madison, USA) was used to analyse the functional groups present on the $K$. alvarezii methanolic extract.

\section{Formulation of herbal hair oil}

The various ingredients used in the formulation of herbal oil are presented in Table 1. The dried and fresh herbs such as K. alvarezii (methanolic extract), Aloe barbadensis miller, Murrays Koenigii and Ocimum tenuiflorum were weighed and grinded in the mixture and mixed in $100 \mathrm{ml}$ of coconut oil. The above content was boiled for 15 mins and was filtered through muslin cloth. Finally, the oil was placed in a bottle [13].

Table 1: Ingredients used in formulation of red seaweed based herbal hair oil

\begin{tabular}{cccc}
\hline S. No. & Constituents & Scientific name & Quantity \\
& & \\
\hline 1 & Red seaweed & Kappaphycus alvarezii (methanol extract) & $20 \mathrm{~g}$ \\
2 & Aloe vera & Aloe barbadensis miller & $5 \mathrm{~g}$ \\
3 & Curry leaves & Murrays Koenigii & $5 \mathrm{~g}$ \\
4 & Tulsi & Ocimum tenuiflorum & $5 \mathrm{~g}$ \\
5 & Coconut oil & Cocos nucifera & $100 \mathrm{ml}$ \\
\hline
\end{tabular}

\section{Evaluation of red seaweed based herbal hair oil preparations:}

The prepared herbal hair oils were subjected to general characterization, physical and biological evaluation.

\section{General characterization:}

The general characters like colour and odour were evaluated manually. 


\section{Physical evaluation:}

The physical evaluation parameters were determined are specific gravity [1], $\mathrm{pH}$, viscosity [5], refractive index, acid value and saponification value [20].

\section{Primary skin irritation test:}

The prepared formulations are assessed for primary skin irritation test on our forearm, little amount of red seaweed based herbal oil, was applied on the test site. The test site was observed for erythema and edema for 3 to $4 \mathrm{hrs}$ [3].

\section{Anti-microbial evaluation (anti-dandruff activity) Cup plate method:}

Diffusion dependent antimicrobial activity of the poly herbal hair oil was studied by the zone of inhibition method. The plate was incubated at $37{ }^{\circ} \mathrm{C}$ for 2 days and the zone of inhibition was measured [21].

\section{Results and Discussion}

\section{Phytochemical Screening}

Phytochemical screening of Kappaphycus alvarezii (methanol extract) confirmed the presence of alkaloids, flavonoids, phenols, tannins, Amino acids, Triterpenoids and Carbohydrate in different qualitative ranges. The negative sign depicted the absence of glycosides and Saponins (Table 2). Renuga et al. (2013) [22] have reported marine organisms are a rich source of structurally novel and biologically active metabolites. Secondary metabolites produced by $K$. alvarezii may be potential bioactive compounds of interest in pharmaceutical industry. Phytochemical screening study of $K$. alvarezii extract revealed that the extract had significant quantity alkaloids, flavonoids, steroid, Terpenoids and absence of glycosides.

Table .1 Qualitative phytochemical screening of Kappaphycus alvarezii (methanol extract)

\begin{tabular}{clc}
\hline S.NO & \multicolumn{1}{c}{ Test } & $\begin{array}{c}\text { Inference [presence } \\
(+) ; \text { absence }(-)]\end{array}$ \\
\hline 1 & Alkaloids & + \\
2 & Flavonoids & + \\
3 & Tannins & + \\
4 & Phenols & + \\
5 & Amino acids & + \\
6 & Carbohydrates & - \\
7 & Saponins & - \\
8 & Glycosides & + \\
\hline
\end{tabular}




\begin{tabular}{lll}
\hline 9 & Triterpenoids & + \\
\hline
\end{tabular}

\section{Antioxidant Activity}

In the present study, $K$. alvarezii methanol extract was analyzed for an antioxidant activity via antioxidant assays (Table 3). The K. alvarezii methanol extract, when subjected to DPPH assay, showed maximum free radical scavenging activity of $72.03 \pm 0.77 \%$ at a concentration of $250 \mu \mathrm{g}$ with $\mathrm{IC}_{50}$ value of $60.06 \pm 0.45 \mu \mathrm{g} / \mathrm{ml}$, thus elucidating the importance of the K. alvarezii (methanol extract) as a potent antioxidant agent (Table 3).

Superoxide anion $\left(\mathrm{O}_{2}{ }^{-}\right)$is an extremely reactive compound synthesized when oxygen is reduced by a single electron and may be produced during the regular catalytic role of various enzymes. Studies report that superoxide anion is highly harmful to cellular components. Robak and Glyglewski (1988) [23] studied that flavonoids are the most effective antioxidants because they scavenge a large range of superoxide anions. In the present study, the superoxide radical scavenging activities of the plant extract had markedly increased with concentrations. The results indicate that the radical scavenging ability of $K$. alvarezii methanol extract was found to be $57.31 \pm 1.43 \%$ at a concentration of $250 \mu \mathrm{g}$ with an $\mathrm{IC}_{50}$ value of $65.88 \pm 1.71 \mu \mathrm{g} / \mathrm{ml}$ (Table 3).

Table.3 In-vitro antioxidant activity of Kappaphycus alvarezii (methanol extract)

Antioxidant assay

Sample concentration

Percentage inhibition

IC50

( $\mu \mathrm{g} /$ reaction volume)

$\%$

$(\mu \mathrm{g} / \mathrm{ml})$

DPPH radical scavenging activity

$\begin{array}{lc} & 100 \\ 150 \\ \text { Super oxide radical scavenging activity } & 200 \\ & 250 \\ & 50 \\ & 100 \\ 150 \\ 200\end{array}$

\section{0}

100

150

200

250

50

100

50

200
$28.71 \pm 1.02$

$42.94 \pm 0.56$

$54.04 \pm 0.56$

$69.75 \pm 1.02$

$72.03 \pm 0.77$

$13.35 \pm 1.23$

$22.33 \pm 0.77$

$34.28 \pm 1.72$

$48.77 \pm 1.62$ 


\section{FTIR Analysis}

Values are expressed as mean \pm SD of triplicates.

The FTIR spectra (Fig. 1) and Table 4 showed significant reduction peaks of methanolic extract $K$. alvarezii. It is evident that most functional groups are extracted in methanolic extract of $K$. alvarezii. From the spectral data it was concluded that the compounds exhibiting activity are probably carbohydrates. The results based on spectral data IR revealed the presence of aliphatic constituents containing Carbon, and hydroxyl groups.

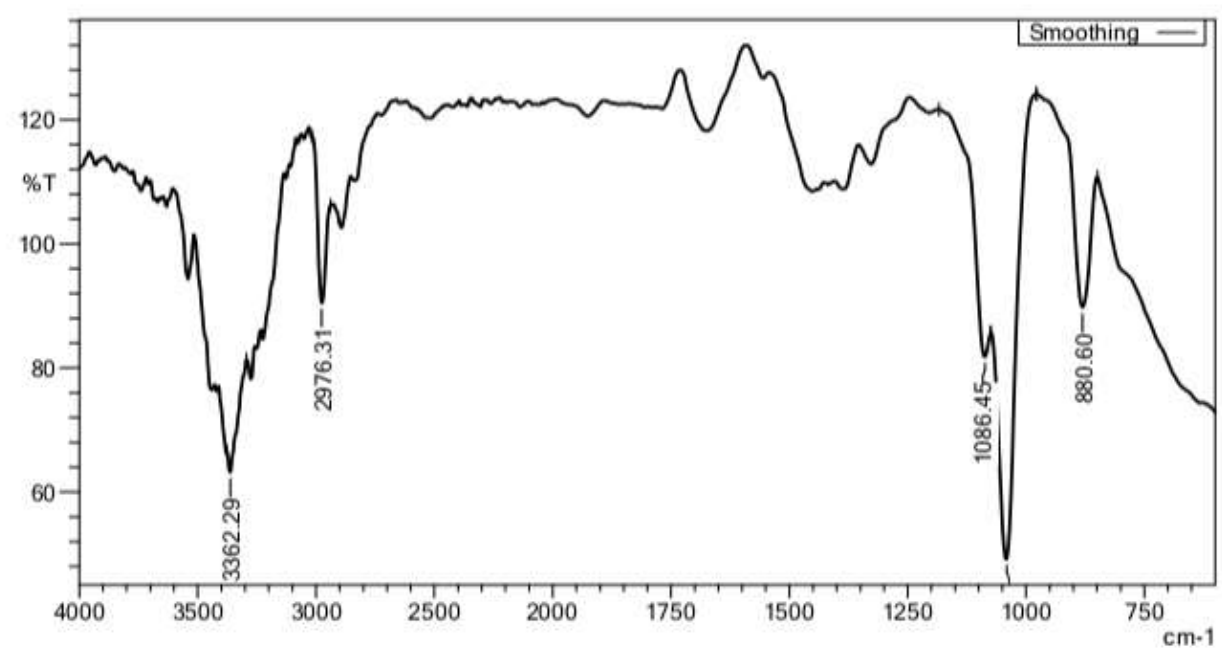

Fig. 1 FTIR spectra of methanolic extract of $K$. alvarezii

Table.4 FTIR functional groups of methanolic extract of $K$. alvarezii

\begin{tabular}{ccc}
\hline S.No & Wave number & Functional group \\
\hline 1 & 880.60 & C-H (1,2,4-trisubstitued) \\
2 & 1040.71 & CO-O-CO (anhydride) \\
3 & 1086.45 & C-O (aliphatic ether) \\
4 & 2976.31 & C-H (alkane) \\
5 & 3362.29 & N-H (aliphatic primary \\
& & amine) \\
\hline
\end{tabular}

Based on the observation the compound may be one of the macro molecules having the characteristic of $\mathrm{CH}, \mathrm{OH}$, and it can be considered the presence of polysaccharide. Once it has purified it will be useful for various application. By the spectral studies of FT-IR inferred 
the presence of polysaccharide compound in the crude extract when compared with standard carrageenan [22].

\section{Physical evaluation of red seaweed based herbal hair oil}

The various parameters like Colour, Odour, Specific gravity (density), pH, Viscosity, Saponification value, Acid value, Refractive index and irritation test, of $K$. alvarezii based poly herbal hair oil were evaluated and the results were presented in Table 5.

Table 5: physical evaluation of herbal hair oil

\begin{tabular}{ll}
\hline Parameters & Results \\
\hline Colour & Dark green \\
Odour & $\begin{array}{l}\text { Pleasant } \\
\text { characteristic } \\
0.82\end{array}$ \\
Specific gravity & 6.9 \\
pH & 0.057 \\
Viscosity & 4.8 \\
Acid value & 23.84 \\
Saponification value & 1.63 \\
Refractive index & No irritation \\
\hline
\end{tabular}




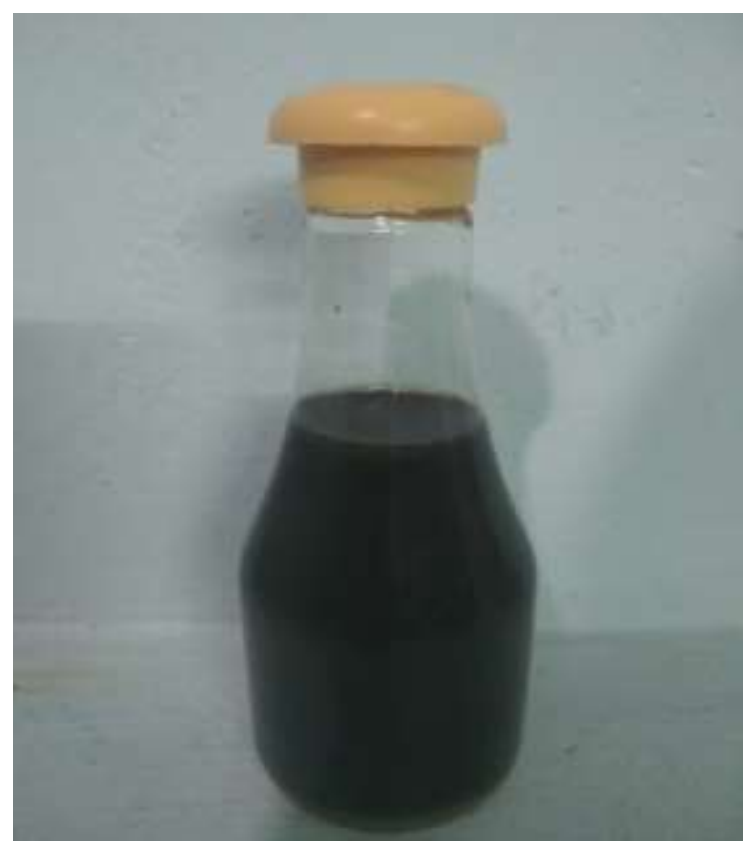

Fig.2 Seaweed based herbal oil

\section{Antimicrobial activity of red seaweed based herbal hair oil}

Antimicrobial activity of red seaweed based herbal hair oil were carried out by cup plate method using Candida albicans organism, results are showed in Table 6.

Table.6 Antimicrobial activity of red seaweed based herbal hair oil

\begin{tabular}{|l|c|c|c|}
\hline \multirow{2}{*}{ Microorganism } & \multicolumn{2}{|c|}{ Zone of inhibition in (mm) } \\
\cline { 2 - 4 } & $\begin{array}{c}\text { Sample } \\
\text { (K. alvarezii based herbal hair oil) }\end{array}$ & $\begin{array}{c}\text { Standard } \\
\text { (Fluconazole) }\end{array}$ & $\begin{array}{c}\text { Control } \\
\text { (Coconut oil) }\end{array}$ \\
\hline Candida albicans & $9.5 \pm 1.0$ & $11 \pm 1.0$ & $0.8 \pm 0.5$ \\
\hline
\end{tabular}

Values are expressed as mean \pm SD of triplicates

The antimicrobial activity of red seaweed based herbal hair oil on test microorganism could be due to the nature of the antimicrobial matters presented in the extracts and their mode of mechanisms.

Hence, from the current study, it was found that the prepared $K$. alvarezii based poly herbal hair oil has optimum standards. Further, hair growth studies have to be carried out to prove that the formulation has significant increase in hair growth activity.

\section{Conclusion}

Herbal formulation has growing demand in the world market. Hence, the current study is a good attempt to establish the herbal hair oil containing methanol extract of seaweed 
and the other herbals. The results of the present study revealed that the developed seaweed based herbal hair oil are rich in phytochemicals and antioxidants. The phytochemicals and antioxidants boost the blood circulation and nutrient supply to the scalp cells which encourages the hair growth, fight against the sun damage by protecting the cuticles, improve the hair growth, prevents the premature greying of hair, and also helps to reduce the frizz and split end. It also has good antimicrobial activity. Since, the seaweed is rich in omega-3 fatty acid, when the scalp receives the goodness of Omega-3, hair follicles get the right amount of nutrients so as to stimulate the growth. All the values in the evaluation of finished product showed that they are within the acceptable limits. These properties of the developed herbal hair oil establish the efficacy of formulated herbal hair oil and it could be marketed commercially.

\section{Acknowledgement}

The authors acknowledge the use of instrumentation and infrastructure facilities provided by DST-FIST, Ministry of science and Technology, and DBT- Star college scheme, Govt. of India for the successful completion of project dissertation. We thank the host institution Dr. N.G.P. Arts and Science College, Management for rendering all the facilities and support. Communication number: DrNGPASC 2020-21 BS078.

\section{References}

1. Gousia Begum S, Sekar M, Ravikumar K, Sekar Keerthana, Design and evaluation f herbal hair oil formulations by using ethanolic exract of Ziziphus jujuba leaves: International journal of pharma and bio sciences, 2017;8(3):322-327.

2. Fatima grace $X$, Rahul raj S, Shanmughanathan S, Chamundeeshwari, Preparation and evaluation of polyherbal hair oil: International journal of pharmaceutical chemistry and analysis, 2014;1(1):2394-2797.

3. Usha Kiran T, Sindhu G, Rajesh S, Aruna B, Sandhya Rani K S, Preparation and evaluation of herbal hair oil: Indo American journal of pharmaceutical sciences, 2017; 4(06):1540-1546.

4. Sabarwal N, Varghese D, B rakesh, K anjali, J ashish, J sanjay, Development and evaluation of polyherbal formulations for hair growth activity: PHCOG J, 2009; 1(2):165170.

5. Amol Joshi A and Pravin dyawarkonda M, Formulation and evaluation of polyherbal hair oil: International journal of green pharmacy, 2017; 11(1):135-139. 
6. Chapman, V. J. 1970. Seaweeds and their uses. London, Methuen, 2nd ed., 304.

7. Rodrigueza, M. R. C., Montaño, M. N. E. 2007. Bioremediation potential of three carrageenophytes cultivated in tanks with seawater from fish farms. Journal of Applied Phycology, 19, 755-762.

8. Artan, M., Li, Y., Karadeniz, F., Lee, S. H., Kim, M. M., Kim, S. K. 2008. AntiHIV-1 activity of phloroglucinol derivative, 6,6'-bieckol, from Ecklonia cava. Bioorganic and Medicinal Chemistry Letters, 16, 7921-7926. http://dx.doi.org/10.1016/j.bmc.2008.07.078.

9. Alekseyenko, T. V., Zhanayeva, S. Y., Venediktova, A. A., Zvyagintseva, T. N., Kuznetsova, T. A. 2007. Antitumor and antimetastatic activity of fucoidan, a sulfated polysaccharide isolated from the Okhotsk Sea Fucus evanescens brown alga. Bulletin of Experimental Biology and Medicine, 143, 730-732. http://dx.doi.org/10.1007/s10517007-0226-4.

10. Cox, S., Abu-Ghannam, N., Gupta, S. 2010. An assessment of the antioxidant and antimicrobial activity of six species of edible Irish seaweeds. International Food Research Journal, 17, 205-220.

11. Kumar, K. S., Ganesan, K., Subba Rao, P.V. 2008. Antioxidant potential of solvent extracts of Kappaphycus alvarezii (Doty) Doty - An edible seaweed. Food Chemistry, 107, 289-295.

12. S. Kaul and S. Dwivedi, Indigeneous Ayurvedic Knowledge of Some Species in the Treatment of Human Disease and Disorders, Int. J. Pharm. Life Sci., 1(1), 44-49 (2010).

13. B. M. Mithal and R. N. Shah, A Hand Book of Cosmetics, 1st Edition, Vallabh Prakashan, Delhi (2000) pp. 141-142.

14. R. Shoba Rani Hiremath Textbook of Industrial Pharmacy, 1st Edition, Orient Longaman Pvt. Ltd., Hyderabad (2007) pp. 99-102.

15. S. C. Bhatia, Perfumes, Soaps, Detergents and Cosmetics, 2nd Edition, CBS Publishers and Distributions, Delhi (2001) pp. 639- 641.

16. Sapna G, Sumeet D, Kushagra D, Hemanth J. Formulation and evaluation of herbal hair oil, International Journal of Chemical Sciences, 2012; 10(1), 349-353.

17. Harborne JB, Trease GE. Phytochemical methods: a guide to modern technique of plant analysis, 3rd edn. Chapman and Hall, London, 1978;114-118

18. Blois MS. Antioxidant determinations by the use of a stable free radical. Nature 1958; 26:1199-1200 
19. Beauchamp C, Fridovich I. Superoxide dismutase: improved assays and an assay applicable to acrylamide gels. Anal Biochem. 1971; 44:276-277

20. Indian Pharmacopoeia 2007; Volume I.

21. Suresh Kumar P, Sucheta S, Umamaheswari A, Sudarshana Deepa V, In vitro and In vivo evaluation of anti-dandruff activity of formulated polyherbal hair oil: Journal of pharmacy research, 2010; 3(12):2956-2958.

22. Renuga G, Osman A and Thandapani AB: Evaluation of Marine algae Kappaphycus alvarezil as a source of natural preservative ingredient. Int J Pharm Sci Res 2013: 4(9); 3548-3555. doi: 10.13040/IJPSR. 0975-8232.4(9).3548-55

23. Robak J, Gryglewski RJ. Flavonoids are scavengers of superoxide anions. Biochem Pharmacol, 1988; 37:837-841 